\title{
High Spatial Resolution Remote Sensing for Salt Marsh Mapping and Change Analysis at Fire Island National Seashore
}

\author{
Anthony Campbell ${ }^{1,2}$ and Yeqiao Wang ${ }^{1, *}$ \\ 1 Department of Natural Resources Science, University of Rhode Island, Kingston, RI 02881, USA; \\ anthony.d.campbell@yale.edu \\ 2 Currently at the Yale School of Forestry \& Environmental Studies, New Haven, CT 06511, USA \\ * Correspondence: yqwang@uri.edu
}

Received: 3 April 2019; Accepted: 6 May 2019; Published: 9 May 2019

\begin{abstract}
Salt marshes are changing due to natural and anthropogenic stressors such as sea level rise, nutrient enrichment, herbivory, storm surge, and coastal development. This study analyzes salt marsh change at Fire Island National Seashore (FIIS), a nationally protected area, using object-based image analysis (OBIA) to classify a combination of data from Worldview-2 and Worldview-3 satellites, topobathymetric Light Detection and Ranging (LiDAR), and National Agricultural Imagery Program (NAIP) aerial imageries acquired from 1994 to 2017. The salt marsh classification was trained and tested with vegetation plot data. In October 2012, Hurricane Sandy caused extensive overwash and breached a section of the island. This study quantified the continuing effects of the breach on the surrounding salt marsh. The tidal inundation at the time of image acquisition was analyzed using a topobathymetric LiDAR-derived Digital Elevation Model (DEM) to create a bathtub model at the target tidal stage. The study revealed geospatial distribution and rates of change within the salt marsh interior and the salt marsh edge. The Worldview-2/Worldview-3 imagery classification was able to classify the salt marsh environments accurately and achieved an overall accuracy of $92.75 \%$. Following the breach caused by Hurricane Sandy, bayside salt marsh edge was found to be eroding more rapidly $\left(\mathrm{F}_{1,1597}=206.06, p<0.001\right)$. However, the interior panne/pool expansion rates were not affected by the breach. The salt marsh pannes and pools were more likely to revegetate if they had a hydrological connection to a mosquito ditch $(\chi 2=28.049, p<0.001)$. The study confirmed that the NAIP data were adequate for determining rates of salt marsh change with high accuracy. The cost and revisit time of NAIP imagery creates an ideal open data source for high spatial resolution monitoring and change analysis of salt marsh environments.
\end{abstract}

Keywords: Salt marsh; change analysis; Worldview-2; Worldview-3; NAIP aerial data; Topobathymetric LiDAR; Fire Island National Seashore

\section{Introduction}

Salt marshes are defined by daily tidal inundation and dominated by halophytic vegetation. These ecosystems are the boundary between terrestrial and nearshore aquatic environments their unique location on the landscape and vegetation composition provides ecosystem services such as denitrification, filtration of pollutants, nursey habitat, coastal resilience, and carbon storage and sequestration [1,2]. Historically, salt marshes have displayed high rates of loss due to land reclamation and disturbances such as mosquito ditching [3,4]. Currently, salt marshes along the mid-Atlantic coastal region of the United States are at risk of loss due to sea level rise (SLR), eutrophication, nutrient enrichment, sediment availability, tidal range, and herbivory and human disturbances [5-12]. Recent 
studies have demonstrated regional and site-specific salt marsh changes including degradation in the Mid-Atlantic [13], proliferation of salt marsh pools in Maryland [14], loss coupled with increased Phragmites on Long Island [15], and loss driven by SLR in New England [16]. However, salt marsh change is a complex combination of persistence, migration, and loss. In the Chesapeake Bay, conversion of uplands to wetlands has mitigated past salt marsh losses [17]. Future salt marsh change is uncertain with some models predicting that salt marsh migration in response to SLR will result in increased salt marsh area [18]. Salt marsh monitoring is necessary for improved understanding of how these ecosystems are changing which in turn can inform their management.

Salt marshes are changing in a variety of ways necessitating a shared nomenclature to discuss these changes. In New England, four types of salt marsh losses have been identified channel widening, interior die-off, shoreline erosion, and loss in the bay head region [16]. These distinctions are dependent on the location of the change. In remote sensing and this study, two major categories were evident change along the edge and change in the interior of the salt marsh. Two types of interior salt marsh loss have been identified: sudden vegetation dieback and drowning. Sudden vegetation dieback in salt marshes is a rapid onset event that persists for a brief period ( $\approx 2$ years) [19]. These die-offs are predominately located in the mid-marsh and have been documented across the eastern Atlantic coast [20]. In contrast, interior drowning driven by sea level rise is outside the scope of these rapid die-off events and represents a fundamental shift in the ecosystem [20]. Monitoring salt marsh change is further complicated by drowning appearing similar to ponding in microtidal salt marshes [21] and pools changing shape dynamically, draining, and revegetating [22]. Monitoring and differentiating between sudden vegetation dieback, drowning, and ponding necessitates high spatial resolution monitoring to assess expansion and recovery dynamics of interior salt marsh areas.

In this study, we focused on estuarine persistent emergent vegetation, i.e. intertidal areas with perennial salt marsh vegetation [23]. We are interested in identifying pools and pannes and how they changed. Pannes are recessed areas of the salt marsh which drain at mean lowest low water (MLLW) and can be vegetated or nonvegetated, in this study we are referring to nonvegetated pannes unless otherwise stated. In comparison pools are those areas of persistent water. Ponding, pools, and pannes are natural elements of the salt marsh landscape, however long-term and widespread loss of vegetation is not. An in situ study of Plum Island estuary, Massachusetts, found pools were in equilibrium with vegetation regrowth occurring after a few years or at most a decade [24]. However, vegetation regrowth is not guaranteed with site-specific characteristics, such as low sediment input, small tidal range, and high regional SLR, contributing to lack of vegetation growth in pannes and slow filling of pools [25]. Identifying these changes in situ is time consuming and non-tenable for large geographic areas. This study presents a method for using satellite and aerial imagery to differentiate between drowning and ponding by monitoring for decades, a temporal period beyond the expected recovery time.

This study is focused on Fire Island, NY, a barrier island, salt marshes on barrier islands have limited land for salt marsh migration. As a result, salt marsh persistence in place is of particular concern, and is a key component of understanding the long-term stability of barrier island systems. Storm events are critical for shaping the geomorphology of barrier islands, e.g., Hurricane Sandy caused overwash on 41 percent of Fire Island depositing an estimated 508,354 $\mathrm{m}^{3}$ of sediment [26] and breached the barrier island. Both overwash and inlet creation are essential sources of sediment accretion in bayside salt marsh environments $[27,28]$. Even thick overwash deposits $(>50 \mathrm{~cm})$ result in quick recovery of the salt marsh vegetation [29]. Mapping salt marsh change following a storm event and breach is critical for our understanding of salt marsh persistence on barrier islands. A previous breach on Fire Island was documented with radiometric dating of salt marsh cores, finding a connection between back-barrier salt marsh formation and inlet creation and the resulting processes [30]. Recent research on anthropogenic alterations of an inlet, i.e., jetty creation, demonstrated changes in local mean sea level (LMSL) and tidal range, which resulted in stabilization of salt marsh directly surrounding the inlet [31]. Similar changes to LMSL and tidal range could be affecting the salt marshes of Fire Island. 
The decision to allow the Fire Island breach to evolve naturally facilitates monitoring to understand the effect of this process on the surrounding salt marshes.

Remote sensing monitoring can quantify essential attributes of the salt marsh landscape. Remote sensing has been used to understand differences in salt marsh pond density and the total surface area between ditched and unditched marshes [32]. Imagery and Light Detection and Ranging (LiDAR) have been used to quantify pools and pannes and their landscape location [33]. Salt marsh change analysis has been used to identify complex patterns of spatial and temporal variation [14], dramatic conversions from high to low marsh [34], impacts of salt marsh restoration and Hurricane Sandy [35], and identify the effect of SLR on salt marsh communities [36]. The combination of very high resolution (VHR) satellite imagery and aerial imagery provided the necessary spatial and temporal resolution to understand the dynamic coastal environment.

This study mapped salt marsh habitat on Fire Island National Seashore (FIIS) utilizing object-based image analysis (OBIA) with VHR satellite imagery. Multitemporal OBIA was utilized to analyze the development and geospatial dynamics of pool and pannes with high spatial resolution aerial imagery from 1994, 2011, 2013, 2015, and 2017. Change to pannes and pools and edge erosion were analyzed to determine if they were significant components of salt marsh loss at FIIS. The use of remote sensing to determine how protected areas are changing with high accuracy is vital to better manage these areas. The objectives of this study are to (1) classify FIIS salt marsh with OBIA and VHR remote sensing imagery data; (2) determine change rates for interior salt marsh pannes and pools and edge erosion from 1994-2017; (3) determine the relationship between hydrological connectivity and panne expansion; and (4) determine if edge erosion or panne/pool expansion increased surrounding the Hurricane Sandy breach between 2011-2017.

\section{Materials and Methods}

\subsection{Study Area}

Fire Island is a barrier island along the southern coast of Long Island, New York, of which 7924 hectares are managed and protected by the National Park Service (NPS) (Figure 1). Salt marsh is the dominant land cover on the island comprising $26 \%$ of the protected area [37]. The bayside environment is polyhaline [38]. The island's geomorphology has been altered by urbanization, beach replenishment, and inlet stabilization [39]. More frequent medium intensity storms have been linked with salt marsh edge erosion [40]. Hurricane Sandy was a 1-in-500-year storm surge event that impacted the northeast Atlantic coastal region on 24 Oct 2012 [41]. In 2003, Quickbird-2 satellite images were used to map the study area with a focus on terrestrial and submerged aquatic vegetation [42]. Due to the limited bayside tidal exchange, Fire Island's salt marshes have a small tidal range of approximately $45.5 \mathrm{~cm}$ between MLLW and MHHW [43]. SLR is outpacing accretion on the salt marshes of Fire Island as determined by Surface Elevation Tables (SET) [5].

Recent estimates of salt marsh change using aerial imagery from 1974 to 2005/2008 found a 14.1\% loss of salt marsh vegetation in a region including Fire Island [15]. The protected areas of FIIS include the William Floyd Estate on the mainland and large bayside islands of Sexton, West Fire and East Fire Island (Figure 1). 

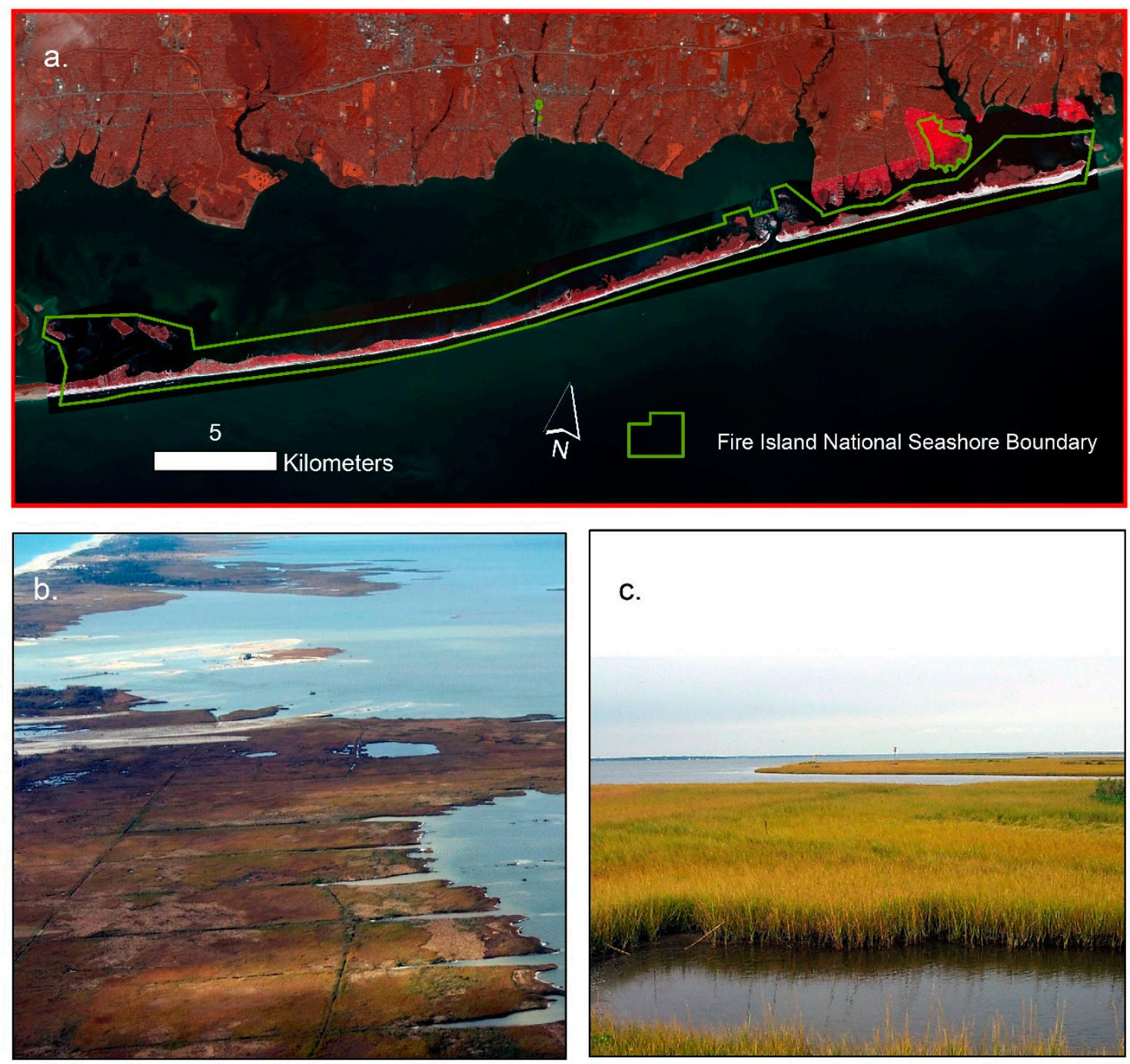

Figure 1. (a) A mosaic of Worldview-2 and Worldview 3 imagery of Fire Island and Sentinel-2 satellite image of the surrounding area (NIR, G, B displayed as R, G, B). (b) A post-Hurricane Sandy oblique aerial view acquired by U.S. Geological Survey (USGS) showing the bayside salt marshes surrounding the breach [44]. (c) A field photo of the Fire Island National Seashore (FIIS) salt marsh landscape.

\subsection{Data}

Satellite imageries were collected on 4/15/2015 and 5/25/2015 with Worldview-3 and Worldview-2 sensors, respectively. Four-band National Agriculture Imagery Program (NAIP) data acquired between 2011 and 2017 and the true color National Aerial Photography Program (NAPP) data acquired in 1994 were used to classify the salt marshes (Table 1). The aerial imageries were collected at a range of tidal stages (Table 1). Change analysis was also conducted with a 1997 classification of FIIS performed with true color aerial photos for the island and verified with in situ field assessment with a highest achieved overall accuracy of $87.5 \%[45,46]$. 
Table 1. The description of data used by acquisition date, spectral resolution (band wavelength when available), sensor or program, and spatial resolution. $\mathrm{R}=$ red, $\mathrm{G}=$ green, $\mathrm{B}=$ blue, NIR = near infrared, $\mathrm{CB}=$ coastal blue, $\mathrm{Y}=$ yellow, $\mathrm{RE}=$ Red edge.

\begin{tabular}{|c|c|c|c|c|}
\hline Date & Spectral Resolution (nm) & Type & $\begin{array}{l}\text { Spatial Resolution } \\
\text { (m) }\end{array}$ & $\begin{array}{c}\text { Tidal Stage } \\
\text { (NAVD 1988) * }\end{array}$ \\
\hline 8 April 1994 & $R, G, B$ & NAPP & 1 & NA \\
\hline 7 May 2011 & $\mathrm{R}, \mathrm{G}, \mathrm{B}, \mathrm{NIR}$ & $\begin{array}{l}\text { LEICA ADS-52 } \\
\text { (NAIP) }\end{array}$ & 1 & $0.02 \mathrm{~m}$ \\
\hline $\begin{array}{l}21 \text { June 2013-22 } \\
\text { June } 2013\end{array}$ & R, G, B, NIR & $\begin{array}{l}\text { ADS40-SH51 } \\
\text { (NAIP) }\end{array}$ & 1 & $-0.21 \mathrm{~m}$ \\
\hline 7 May 2015 & $\begin{array}{l}\text { R (619-651), G (525-585), B } \\
(435-495), \text { NIR (808-882) }\end{array}$ & $\begin{array}{l}\text { Leica ADS-100 } \\
\text { (NAIP) }\end{array}$ & 0.5 & $-0.29 \mathrm{~m}$ \\
\hline $\begin{array}{l}9 \text { August } 2017 \& \\
27 \text { August } 2017\end{array}$ & $\begin{array}{c}\text { R (619-651), G (525-585), B } \\
(435-495), \text { NIR (808-882) }\end{array}$ & $\begin{array}{l}\text { Leica ADS-100 } \\
\text { (NAIP) }\end{array}$ & 1 & $0.09 \mathrm{~m}$ \\
\hline $\begin{array}{c}25 \text { May } 2015 \& 15 \\
\text { April } 2015\end{array}$ & $\begin{array}{c}\text { CB }(400-450), \text { B }(450-510), \text { G } \\
(510-580), \text { Y (585-625), R } \\
\text { (630-690), RE (705-745), NIR1 } \\
(770-895), \text { NIR2 (860-1040) }\end{array}$ & Worldview-2/3 & 0.5 & $-0.29 \mathrm{~m}$ \\
\hline $\begin{array}{c}8 \text { January 2014-22 } \\
\text { May } 2014\end{array}$ & Green and NIR & $\begin{array}{l}\text { Leica ALS 50-II } \\
\& \\
\text { Riegl sensor } \\
9999609\end{array}$ & $\begin{array}{c}\text { 0.5 Digital } \\
\text { Elevation Model }\end{array}$ & NA \\
\hline
\end{tabular}

* Average tidal stage across the acquisition as derived from USGS tidal gauge 01309225 [47].

\subsection{Tidal Stage Effects}

The effects of the tidal stage at the time of imagery acquisition on mapped salt marsh extent has long been recognized e.g., $[48,49]$. In this study, the tidal stage could impact the edge erosion calculations and the panne analysis. Therefore, the highest tidal stage out of all the imageries was analyzed using topobathymetric LiDAR, bathtub models, and the 2015 FIIS classification [50]. The method utilized the topobathymetric LIDAR-derived Digital Elevation Model (DEM) to create a bathtub model, i.e., a binary raster of inundated and non-inundated pixels, at the target tidal stage. The highest tidal stage of our images was $35.66 \mathrm{~cm}$ MLLW or $14.3 \mathrm{~cm}$ above the North American Vertical Datum 1988 (NAVD 88) occurring in 2017. The bathtub model was then used to determine areas mapped as vegetated in 2015 that were likely inundated at the 2017 image's tidal stage. The method has been applied in Jamaica Bay, New York, and was utilized in this study to understand the potential impact tidal stage had on the aerial image classifications. These data provide an understanding of the uncertainty derived from inundation that could occur in this analysis.

\subsection{Object-Based Image Analysis}

OBIA begins with an unsupervised classification or segmentation dividing the image into areas with similar spectral characteristics and spatial proximity [51]. This method used mean shift segmentation: a hierarchical segmentation with demonstrated success in remote sensing and other disciplines [52,53]. OBIA allows for the combination of spectral, spatial, and ancillary data and has been shown to increase classification accuracy compared to pixel methodologies when using VHR satellite imagery [54-56]. In this study, a multiscale segmentation approach was used, selecting under segmented areas and resegmenting them at a finer segmentation scale $[57,58]$ (Figure 2). This study's final segmentation was dual scale with $80 \%$ of objects segmented at a spectral radius of 13 and minimum size of five pixels. The other $20 \%$ were segmented at a spectral radius of 8 and minimum size of five pixels. Data processing and segmentation were conducted with Python 2.7 [59] and Orfeo Toolbox 5.2 [60]. 


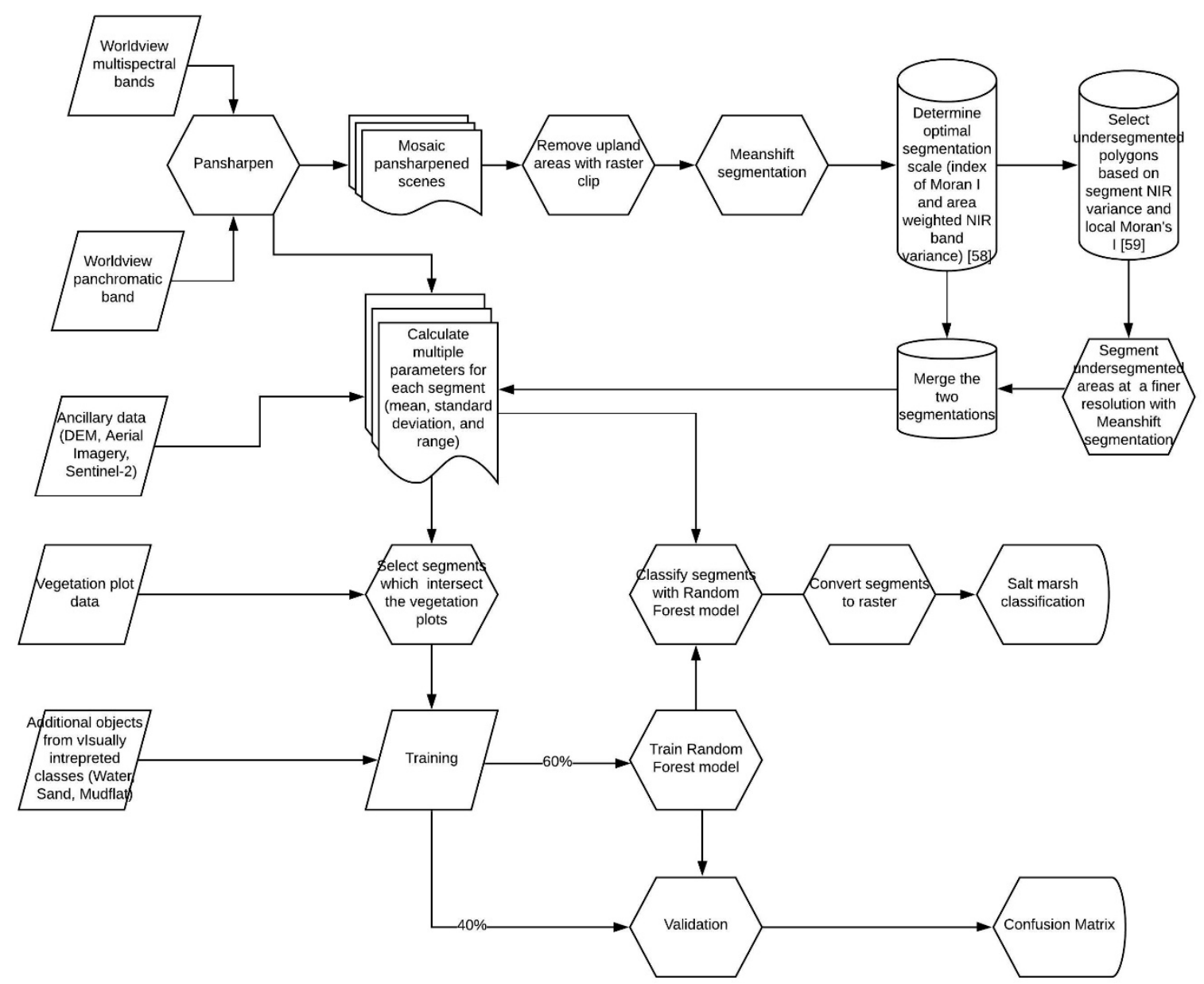

Figure 2. The data processing and classification workflow for classification of the Worldview-2 and Worldview-3 imagery.

The classification was composed of 10 categories including S. alterniflora, patchy S. alterniflora, high marsh, upland, dune vegetation, sand, mudflat, water, Phragmites, and wrack. A one-thousand-nine-hundred-and-thirteen $1-\mathrm{m}^{2}$ vegetation plot data were adapted to create training data. The training data were composed of plots with a Braun-Blanquet percent cover greater than $\geq 50 \%$. Objects that intersected training points were selected, resulting in a total of 1964 training samples. The species included in the high marsh category were S. patens, D. spicata, I. frutescens, and J. gerardii. Percent cover differentiated the two S. alterniflora classes with the patchy S. alterniflora class being between 49 and $10 \%$ cover, and the $S$. alterniflora class being $\geq 50 \%$ cover. The vegetation plots were predominantly within the salt marsh environment leading to water, sand and upland classes being trained from samples gathered by visual interpretation and field knowledge. The Random Forest (RF) classifier was used to classify the 2015 Worldview-2/Worldview-3 image data for vegetation mapping and the panne and edge classifications.

Accuracy assessment was conducted for the 2015 Worldview-2/Worldview-3 image classification using a subset of the total training data. The data were randomly split $60 \%$ training and $40 \%$ for testing. The training data were used to train the RF model. An error matrix including kappa, producers, users, and overall accuracies was computed using the testing data.

The 2015 image classification was compared with a 1997 classification based on aerial imagery [45]. The 1997 classes of Reed grass marsh, high marsh, low marsh, and mosquito ditches were compared with the 2015 classes of Phragmites, high marsh, and S. alterniflora classes accordingly. Mosquito ditches in 1997 were included as vegetated area due to their small average width reported from 25.4 to $50.8 \mathrm{~cm}$ [61]. This width is below the minimum mapping unit of 0.25 ha for the 1997 classification [45] 
and the three-pixel width of the VHR classification. Change rate was calculated between 2015 and the 1997 salt marsh.

\subsection{Change Analysis (1994-2017)}

The panne and pool analysis, subsequently referred to as panne analysis, was conducted on imageries from 1994 to 2017. The edge erosion change analysis was conducted for 1994 to 2011 and 2011 to 2017. Each image collection was segmented at a spectral radius of 10 and shape radius of 5 with mean shift segmentation. This segmentation scale was adequate given the lower spectral resolution of the aerial images. ArcMap 10.5 [62] was used to select segments which intersected the interior mud or water areas of 2015 Worldview-2/Worldview-3 classifications, these segments comprised the 2015 pannes. The segments were then merged, creating a multitemporal segmentation. The classification parameters included mean, median, standard deviation, simple indices (i.e., red band/blue band), normalized difference vegetation index (NDVI) for those years with NIR, and the difference of each band for the year of interest and subsequent year. The panne and edge classifications were trained with objects that were either vegetated or non-vegetated. Their accuracies were verified with 522 randomly selected points, which were assessed as vegetated or non-vegetated for each time period.

\subsection{Statistical Analysis}

Edge erosion was calculated for two periods from 1994 to 2011 and 2011 to 2017. The salt marsh edge erosion was calculated based on starting edge length and the total area lost for each edge erosion object. Welch ANOVAs were used to compare rates of change from 1994 to 2011 and 2011 to 2017 for both pannes and edge erosion. Least-squares means was used to compare the two edge erosion rates and to see if edge erosion had increased following the hurricane breach and how this varied between barrier island, bayside islands, and the mainland. A two-way ANOVA was used to compare panne yearly change rates before and after the breach and between barrier island, bayside islands, and the mainland. Annual salt marsh change rates were compared with a Kruskal-Wallis rank sum test, a nonparametric statistical test, followed by a Wilcoxon rank sum test. Linear regression models were used to test the relationship between edge erosion and distance from the breach for the period 2011 to 2017 for $2000 \mathrm{~m}$ in both directions. A beta regression ANOVA-like table was produced testing the relationship between the percent change from 2015 to 2017 of interior areas with and without mosquito ditch hydrological connections. All statistical analysis was done within the R 3.5.1 statistical environment [63].

\section{Results}

\subsection{OBIA Classification}

The 2015 Worldview-2/Worldview-3 image classification achieved an overall accuracy of $92.75 \%$ (Table 2). Visual inspections revealed an appealing result with an appropriate gradient from S. alterniflora, high marsh, Phragmites, and upland vegetation (Figure 3). Errors were mostly between the two types of $S$. alterniflora due to their spectral similarities and early seasonal acquisition date of the imagery. There was no confusion between mudflat/water and other classes making this classification an ideal baseline for change analysis.

The 2015 Worldview-2/Worldview-3 imagery classification was compared with a 1997 classification conducted with aerial imagery. When comparing salt marsh vegetation between the two periods a reduction from 531.27 ha to 505.95 ha was observed or 1.41 ha $^{-1}$. 
Table 2. An error matrix for the 2015 Worldview-2/Worldview-3 classification of Fire Island National Seashore.

\begin{tabular}{|c|c|c|c|c|c|c|c|c|c|c|c|c|}
\hline & \multicolumn{12}{|c|}{ Reference Data } \\
\hline & Class & $\begin{array}{c}\text { Dune } \\
\text { Vegetation }\end{array}$ & $\begin{array}{l}\text { High } \\
\text { Marsh }\end{array}$ & Mudflat & Phragmites & Sand & $\begin{array}{c}\text { Patchy } S . \\
\text { alterniflora }\end{array}$ & $\begin{array}{c}S . \\
\text { alterniflora }\end{array}$ & Upland & Water & Wrack & $\begin{array}{c}\text { User's } \\
\text { Accuracy }\end{array}$ \\
\hline \multirow{11}{*}{ 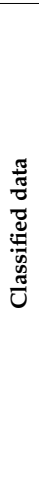 } & Dune Veg. & 36 & 0 & 0 & 0 & 0 & 0 & 0 & 0 & 0 & 0 & 100 \\
\hline & High marsh & 0 & 61 & 0 & 1 & 0 & 0 & 6 & 2 & 0 & 0 & 87.1 \\
\hline & Mudflat & 0 & 0 & 30 & 0 & 0 & 0 & 0 & 0 & 0 & 0 & 100 \\
\hline & Phragmites & 0 & 0 & 0 & 15 & 0 & 0 & 0 & 0 & 0 & 0 & 100 \\
\hline & Sand & 0 & 0 & 0 & 0 & 26 & 0 & 0 & 0 & 0 & 0 & 100 \\
\hline & $\begin{array}{c}\text { Patchy } S \text {. } \\
\text { alterniflora }\end{array}$ & 0 & 0 & 0 & 0 & 0 & 34 & 14 & 0 & 0 & 0 & 70.8 \\
\hline & S. alterniflora & 0 & 3 & 0 & 0 & 0 & 0 & 79 & 0 & 0 & 0 & 96.3 \\
\hline & Upland & 0 & 0 & 0 & 0 & 0 & 0 & 0 & 40 & 0 & 0 & 100 \\
\hline & Water & 0 & 0 & 0 & 0 & 0 & 0 & 0 & 0 & 40 & 0 & 100 \\
\hline & Wrack & 0 & 1 & 0 & 0 & 1 & 0 & 0 & 0 & 0 & 10 & 83.3 \\
\hline & $\begin{array}{l}\text { Producer's } \\
\text { Accuracy }\end{array}$ & 100 & 93.8 & 100 & 93.8 & 96.3 & 100 & 79.8 & 95.2 & 100 & 100 & $\begin{array}{l}\text { OA: } \\
92.75\end{array}$ \\
\hline
\end{tabular}
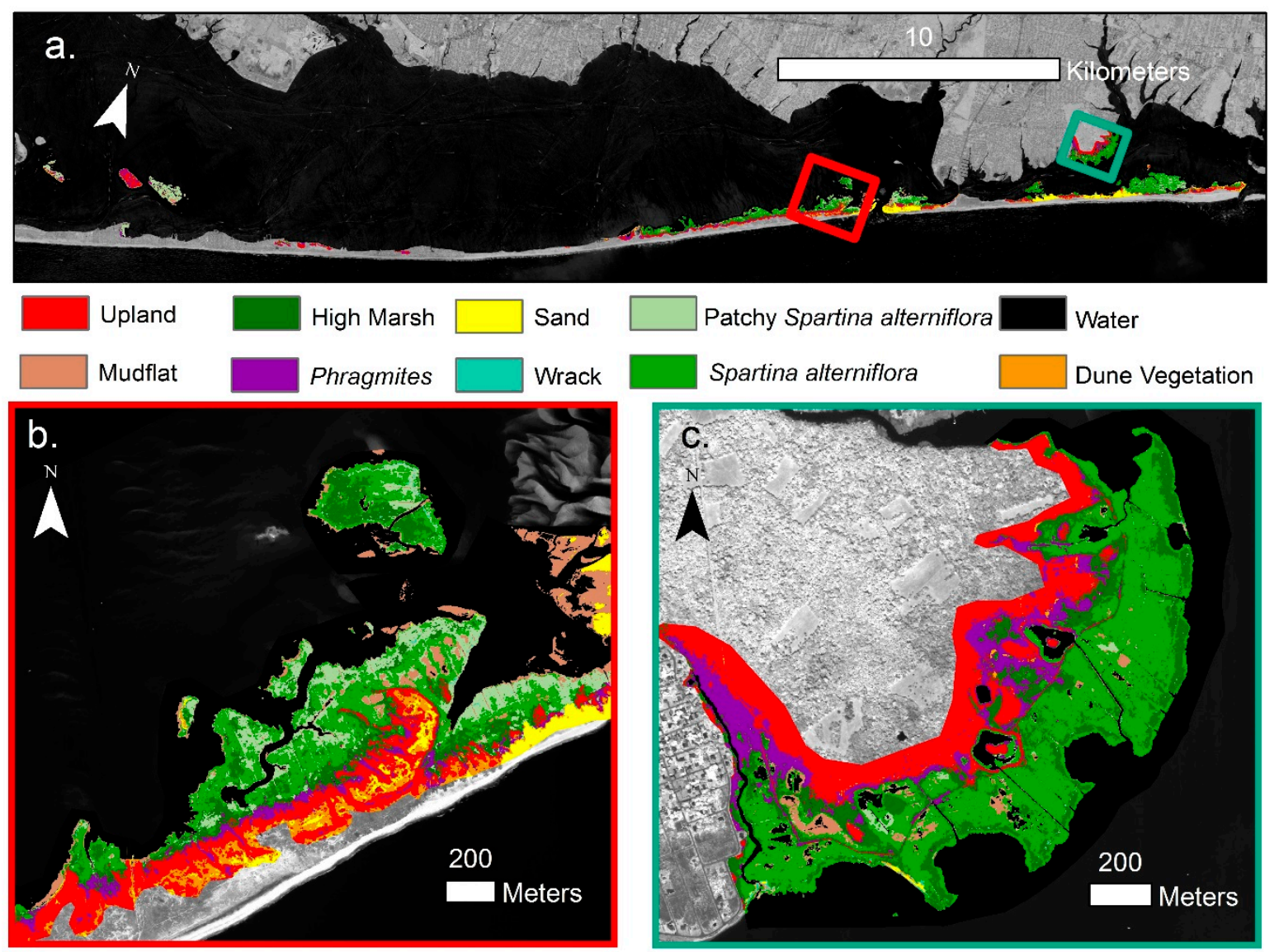

Figure 3. (a) The 2015 Worldview-2/Worldview-3 image classification of salt marshes in FIISs. (b) A section of FIIS directly to the west of the old inlet breach. (c) The Floyd Bennet estate, a section of FIIS on the mainland.

\subsection{Tidal Stage Effect}

The 2017 NAIP imageries were acquired at an approximate tidal stage of $35.66 \mathrm{~cm}$ above MLLW at U.S. Geological Survey (USGS) 01305575 at Watch Hill [43]. The 2014 DEM derived from topobathymetric LiDAR was used to determine how much inundation of S. alternilflora would be expected at this elevation. The analysis found $7.39 \%$ of the 2015 classification's S. alterniflora classes were inundated. The indundation could be subcanopy and have little impact on the 2017 classification. 
The areas of modeled inundation were most prevalent in mosquito ditches, sandbars, and interior mudflats (Figure 4).

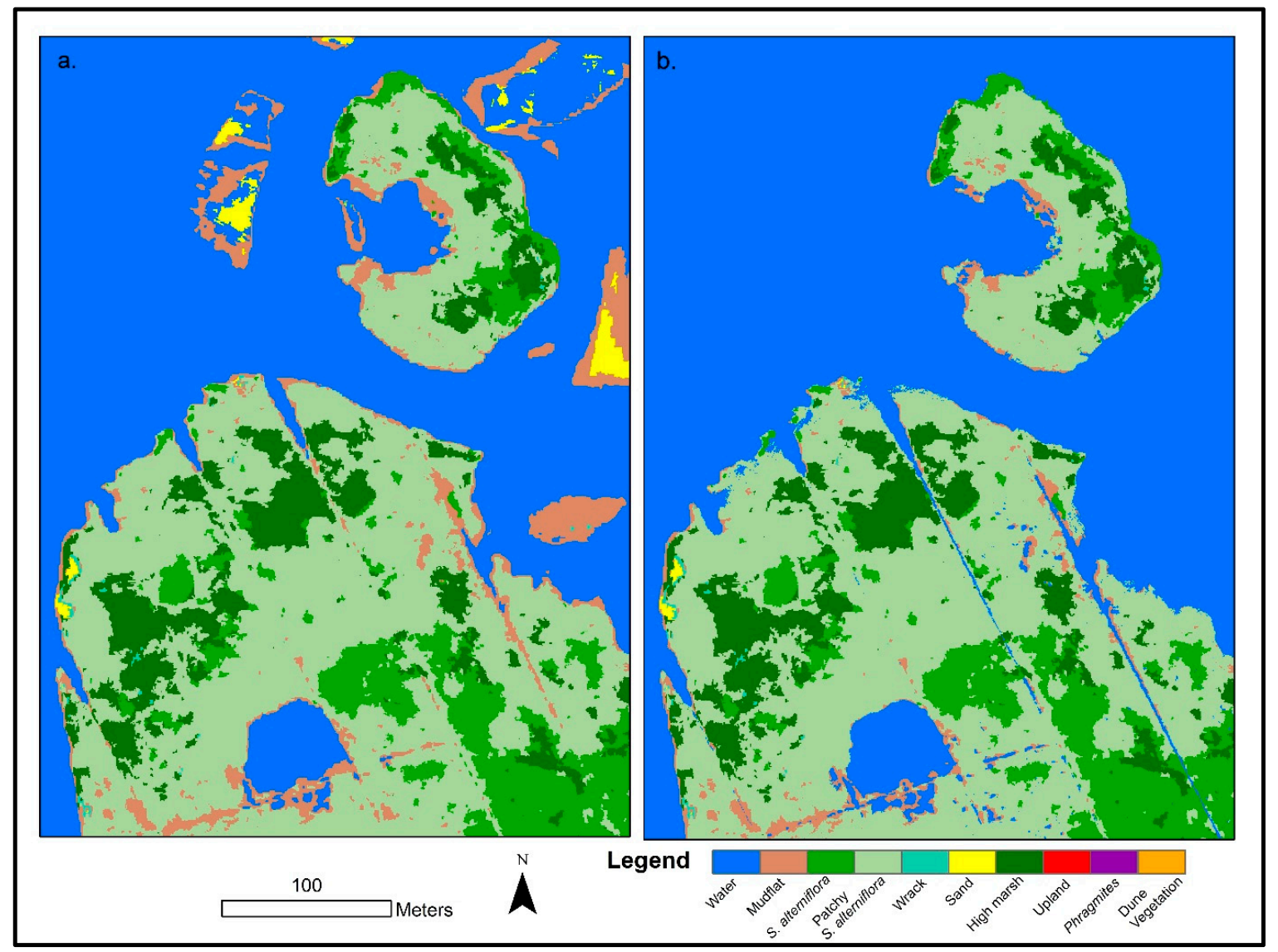

Figure 4. (a) The 2015 Worldview-2 and Worldview-3 Classification for a section of Fire Island east of the breach. (b) The modeled tidal inundation of the 2015 classification at a tidal stage of $14.3 \mathrm{~cm}$ above NAVD 88, which corresponded to the highest tidal stage of the imagery used in the study.

\subsection{Change Analysis (1994-2017)}

The panne change analysis achieved overall accuracy $>85 \%$ for all years (Table 3 ). However since these classifications were being used in tandem it is important to note that propogated percent error calculated by the square root of the sum of squares was 16.7,10.2, 11.8, and 13.1 for 1994-2011, 2011-2013, 2013-2015, and 2015-2017, respectively. Models with low overall accuracies were evaluated and manually digitized when necessary. The analysis included 475 pannes mapped in 2015 that were $>10$ square meters. In 2015, the mean panne size was $441.6 \mathrm{~m}$ compared to the 1994 mean size of $121.4 \mathrm{~m}$. In 1994, 257 of the 475 pannes were vegetated. The mean yearly rates of panne change for each of the periods were 25.00, 5.34, 27.98, and $15.91 \mathrm{~m}^{2} \mathrm{y}^{-1}$ for 2015-2017, 2013-2015, 2011-2013, and 1994-2011, respectively (Figure 5). There were statistical differences between the yearly change rates $\left.\left(\mathrm{H}_{3}\right)=30.097, p<0.001\right)$ were compared with the Wilcoxon rank sum test (Table 4$)$. There were significant differences between edge erosion rates between 1994 and 2011 and 2011 and $2017\left(F_{1,1597}\right.$ $=206.06, p<0.001)$. There were no significant differences between panne change in 1994-2011 and 2011-2017 $\left(\mathrm{F}_{1,948}=0.13, p=0.72\right)$. The edge erosion rates for the mainland, bayside islands, and barrier island locations were compared before and after the Hurricane Sandy breach with least-square means (Figure 6). Pannes, in general, became larger from 1994 to 2017, the temporal resolution from 2011-2017 shows fluctuation in these increases (Figure 7). In 2015-2017, pannes were more likely to revegetate if they had a hydrological connection to a mosquito ditch $(\chi 2=28.049, p<0.001)$. Edge erosion to the east of the breach from 2011 to 2017 had a significant linear trend $\left(F_{1,27}=28.2, p<0.001\right)$ and an $R^{2}$ of 0.51 . 
Edge erosion to the west of the breach from 2011-2017 had no trend $\left(\mathrm{F}_{1,94}=1.5, p=0.22\right)$ and an $\mathrm{R}^{2}$ of 0.02 .

Table 3. Panne and edge overall classification accuracies, 1994-2015.

\begin{tabular}{cccc}
\hline Year & Overall Accuracy (\%) & Image Source & Spatial Resolution $(\mathbf{m})$ \\
\hline $\mathbf{2 0 1 7}$ & 92.4 & NAIP & 1 \\
\hline $\mathbf{2 0 1 5}$ & 89.3 & NAIP & 0.5 \\
\hline $\mathbf{2 0 1 3}$ & 95.0 & NAIP & 1 \\
\hline $\mathbf{2 0 1 1}$ & 91.1 & NAIP & 1 \\
\hline $\mathbf{1 9 9 4}$ & 85.88 & NAPP & 1 \\
\hline
\end{tabular}

Total Pannes

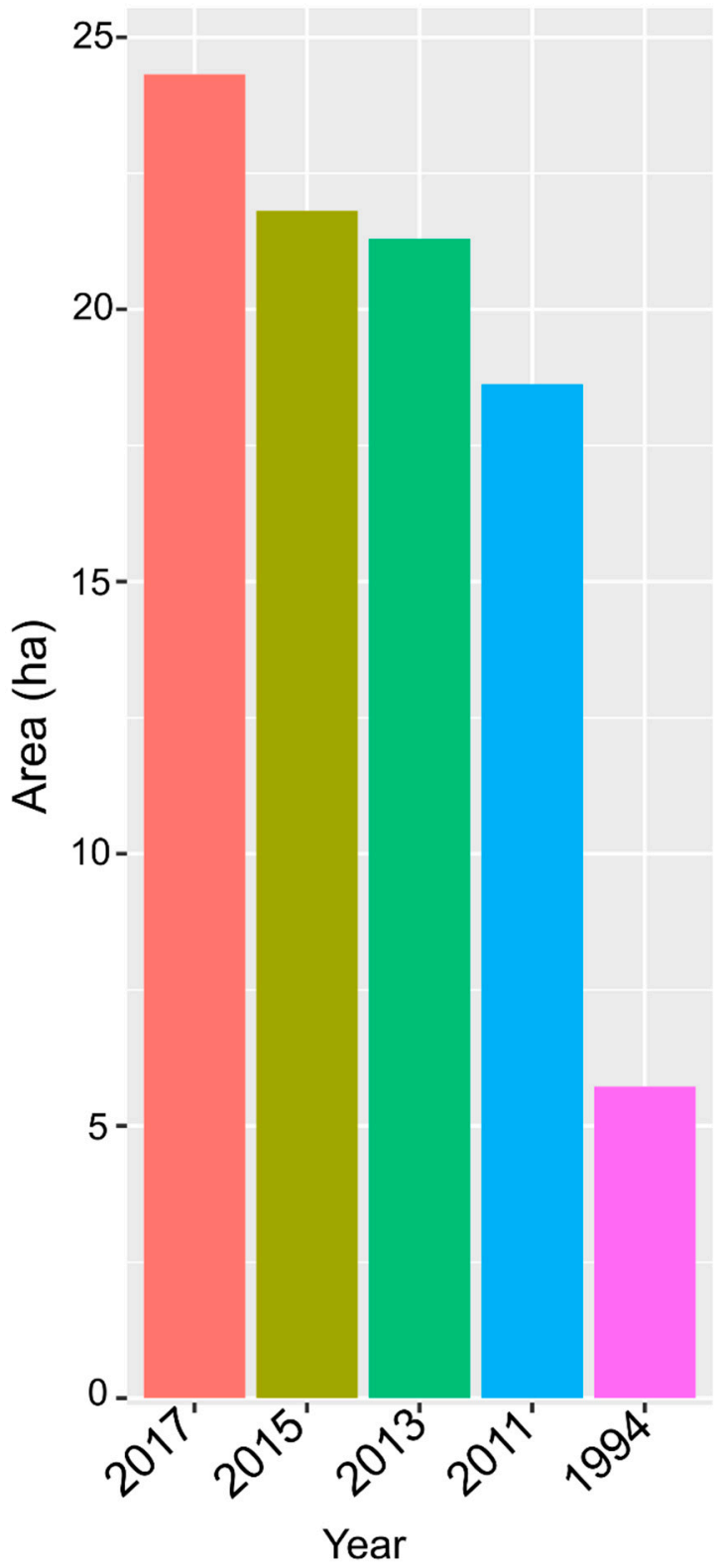

Mean Change Rate

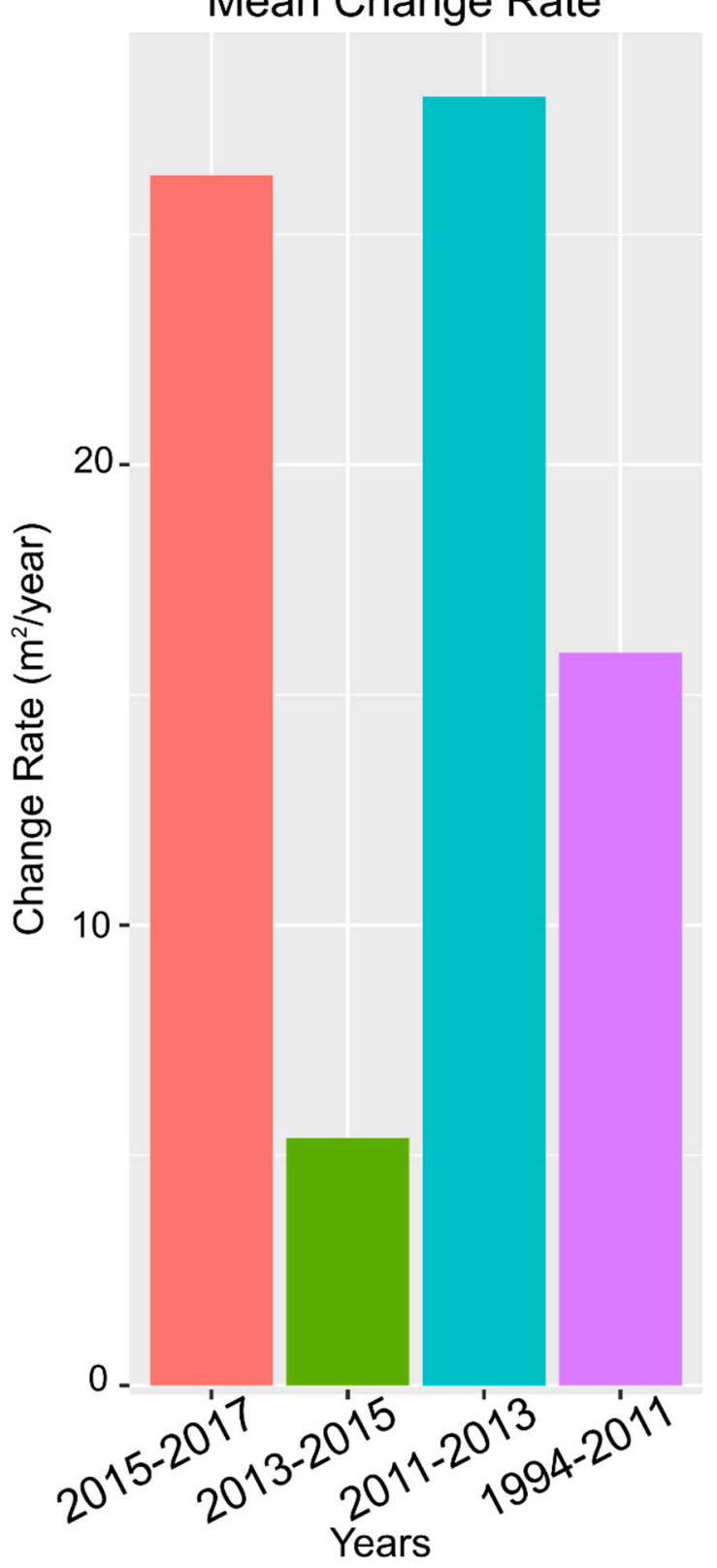

Figure 5. Interior pannes total area and change rates from (1994-2017) both the average yearly change rates of a time period and total area of pannes and pools. 
Table 4. Wilcoxon rank sum test between annual panne change rates.

\begin{tabular}{cccc}
\hline Years & 2017-2015 & 2015-2013 & 2013-2011 \\
\hline 2015-2013 & $p<0.05$ & & \\
\hline 2013-2011 & $p=0.72$ & $p<0.72$ & \\
\hline 2011-1994 & $p<0.001$ & $p<0.72$ & $p<0.001$ \\
\hline
\end{tabular}

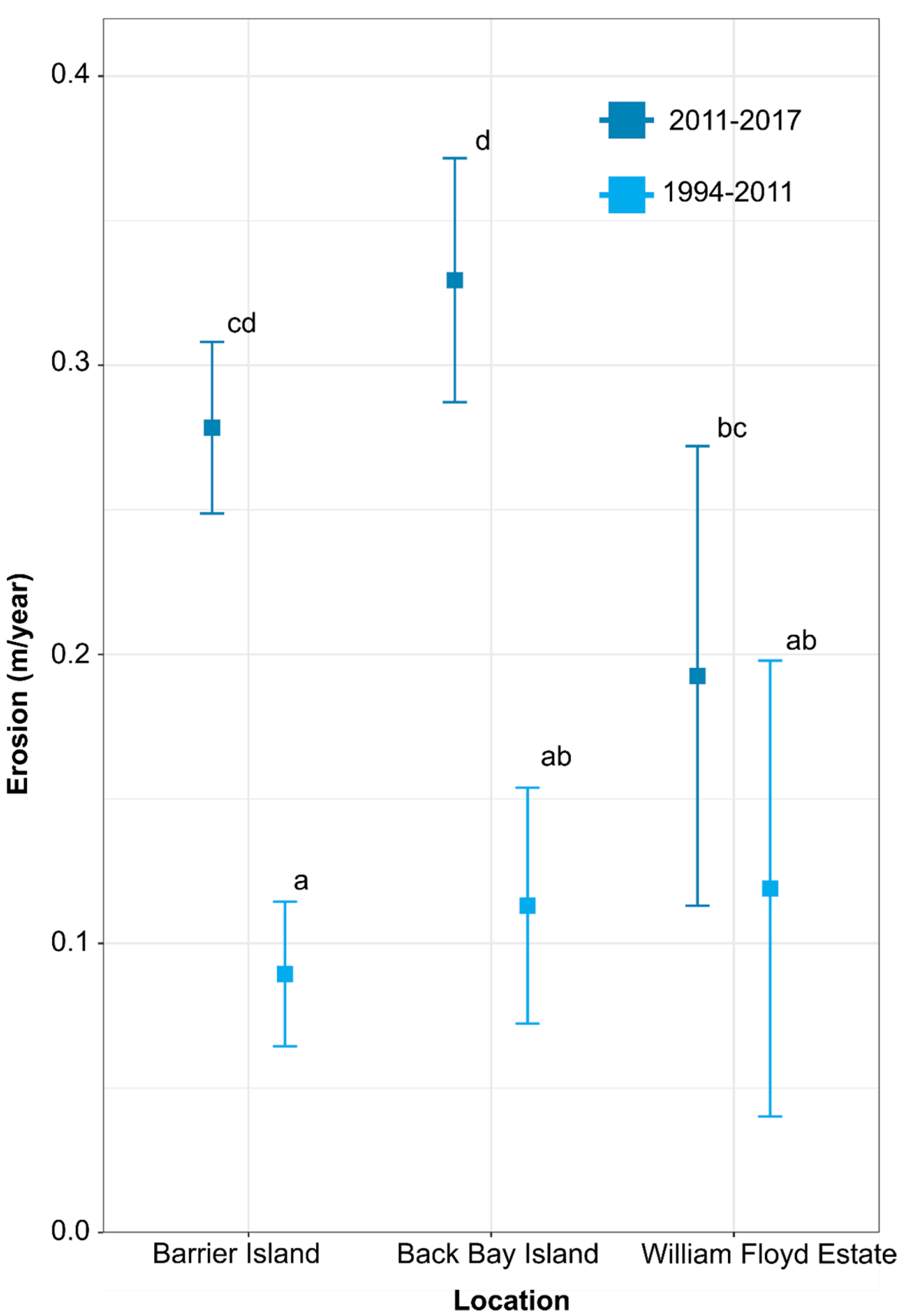

Figure 6. Edge erosion rates compared by time period (1994-2011, 2011-2017) and location (barrier island, mainland, or back bay island) with least square means with Bonferroni $p$-value adjustment. Location/dates that share letters did not demonstrate significant differences $(p>0.05)$. 


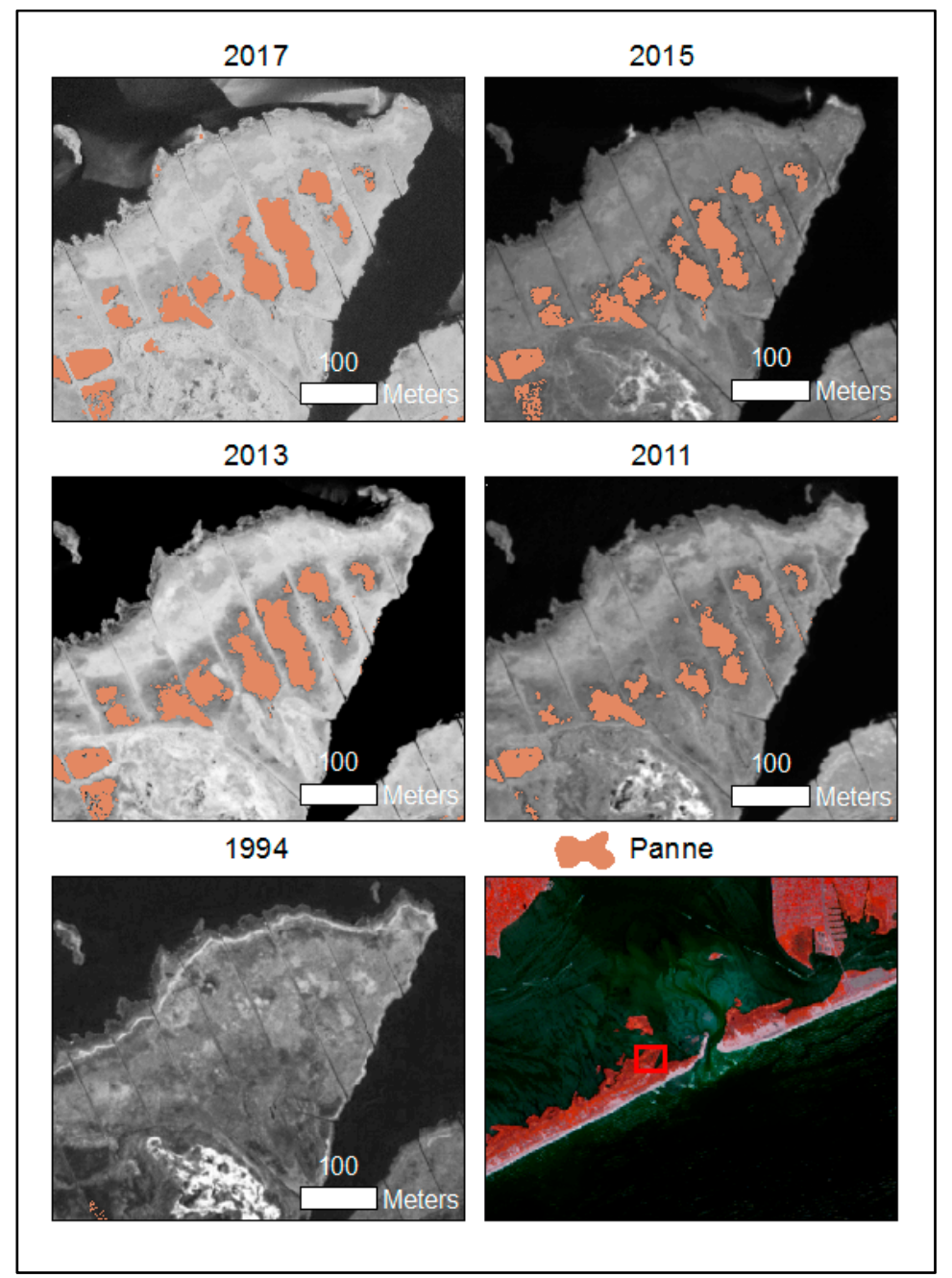

Figure 7. Panne classification from 1994 to 2017 for an area to the west of the old inlet breach. Each inset has the corresponding years NIR in panchromatic or red band in 1994. The locus map is a Sentinel-2 image from 5/21/2016.

\section{Discussion}

The change analysis between the 1997 classification and the 2015 classification revealed salt marsh loss (Figure 8). High marsh area fell from 199.6 ha to 109.8 ha. Previous studies mapping salt marsh change from 1974 to 2005/2008 for the entirety of Long Island, NY found similar change, including a $35.5 \%$ reduction in the high marsh for a region from Fire Island inlet to Smith Point, and a decrease in Phragmites on the south shore [15]. The conversion of upland and Phragmites to low and high marsh categories suggests salt marsh migration in response to SLR. The utility of the comparison between 1997 and 2015 was limited due to the different classification schemes.

In general, pannes/pools demonstrated several periods of statistically significant expansion. Of the 475 pannes, $46 \%$ were present in 1994. Meaning there was a doubling of pools and pannes from 1994 to 2015. Two hundred and twelve of the 475 pannes were in areas classified as high marsh in 1997. These pannes accounted for 12.51 ha out of a total of 21.81 ha, i.e., the largest area of pannes occurred in the high marsh. These non-vegetated pannes/pools are essentially tidal mudflats which provide some essential ecosystems services. However, ecosystem service valuations suggest salt marsh to be over five times more valuable than mudflats [64].

The expected evolution of an interior salt marsh pool is expansion until hydrological connectivity is established leading to drainage and possible vegetation regrowth [22]. In our analysis, pannes/pools connected to mosquito ditches in 2015 had a mean change rate of $-3.52 \mathrm{~m}^{2} \mathrm{y}^{-1}$ compared to $30.87 \mathrm{~m}^{2} \mathrm{y}^{-1}$ 
for non-hydrologically connected pannes/pools. This is encouraging for the possibility of vegetation regrowth. However, natural creeks are infrequent landscape features having remained relatively stable from 1930 to 2007 [61]. In contrast mosquito ditches are common across Fire Island, leading to hydrological connectivity with mosquito ditches being common. However, besides providing a hydrological connection, mosquito ditches likely drive drowning by altering marsh hydrology, and plugged mosquito ditches cause subsidence and loss of salt marsh function [65]. Additionally, the berms surrounding ditches can lead to poor drainage [66]. Highly variable accumulation of sediment in Fire Island's mosquito ditches has led to the infill of some ditches and little to no accumulation in others [61] (Figure 8). The varied rate of infilling could be influencing observed rates of panne/pool expansion. The landscape legacy of the mosquito ditches is a site-specific factor that is critical for understanding salt marsh change on Fire Island.
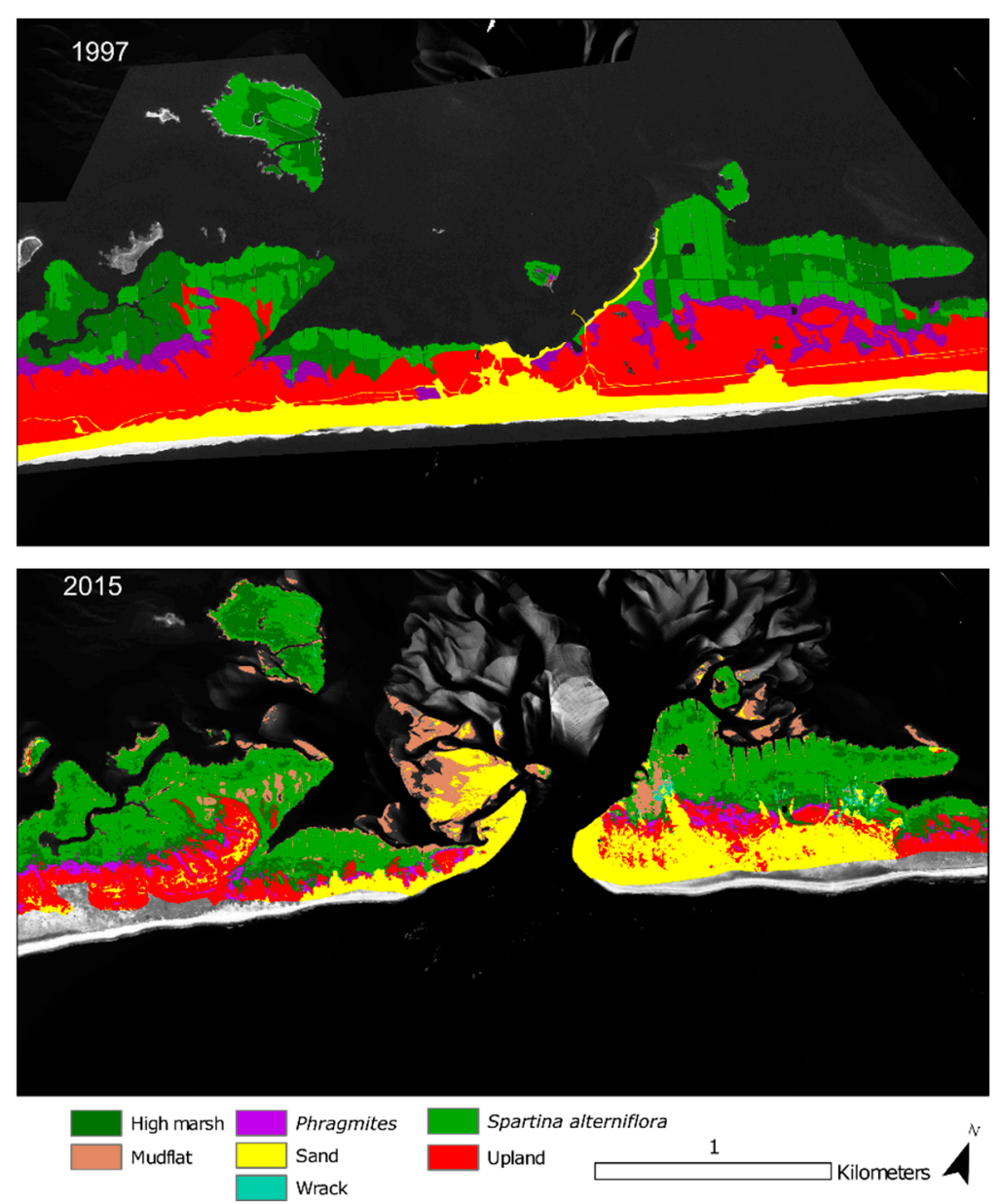

Figure 8. Land cover of the area surrounding the 2012 Fire Island breach for 1997 and 2015. Land cover change both due to the breach and overwash are evident in the 2015 classification. Spartina alterniflora classes are shown as a single class due to the 1997 class no differentiating between percent cover. Upland and dune vegetation classes are also shown as a single class.

Whether vegetation regrowth occurred within the pannes/pools is a critical question. Vegetation regrowth is limited by the growth range of $S$. alterniflora at the site. The lowest elevation of living S. alterniflora at the site was $25.7 \mathrm{~cm}$ below NAVD 1988 [67]. The minimum growing elevation of S. alterniflora for FIIS was determined using the tidal range of $45.5 \mathrm{~cm}$ and the methods of [10]. Finding a minimum growth elevation of $12.7 \mathrm{~cm}$ below NAVD 1988, which is a more conservative estimate than the observed minimum growth elevation. Six of the 475 pannes analyzed were below the vegetation range of $S$. alterniflora at the site, meaning vegetation could grow on nearly all of the observed pannes. 
However, only 30 of the 4752015 pannes/pools were entirely vegetated in 2017. Complete vegetation regrowth was rare but did occur in the pannes and pools analyzed.

Significant increases in edge erosion were observed following the breach. These areas likely experienced changes in currents, wave energy, or LMSL. For example, the William Floyd estate site saw no significant difference in edge erosion before and after the breach. This site is approximately $8 \mathrm{~km}$ away from the breach and approximately $5 \mathrm{~km}$ from the stabilized Moriches Inlet. In contrast, the area immediately surrounding the breach to the east experienced significant loss from increased edge erosion. An increase in edge erosion as you neared the breach was evident towards the east. However, there was no such trend to the west of the breach. The high variability of the bayside salt marsh erosion demonstrates the importance of geospatial monitoring to understand how these systems are changing spatially. As previous studies reported, Surface Elevation Table (SET)-derived accretion estimates at the site are below the rates of SLR [5]. FIIS' wilderness areas have little infrastructure limiting the migration of salt marsh. However, the islands width and interconnectedness of the barrier island systems means salt marsh migration alone will not maintain the barrier island.

The bayside of barrier islands have low energy and small tidal range (Watch Hill, NY on Fire Island's tidal range is $45.5 \mathrm{~cm}$ between MLLW and MHHW [43]), which can result in slower expansion of pools due to edge erosion [25]. The establishment of an inlet can cause an increase in tidal range; however, there were no statistical differences between panne/pool expansion rates between the examined time periods (1994-2011 and 2011-2017). Possibly due to the scarcity of pools in our analysis which would be expected to expand more rapidly with increased tidal range. The breach caused by Hurricane Sandy did not appear to accelerate or slow the interior salt marsh change. However, edge erosion significantly increased following the breach. Continued monitoring is necessary to determine if the observed trend continues.

\section{Conclusions}

This study evaluated panne/pool development and fluctuations with remote sensing, identifying spatial and temporal patterns of coastal marsh habitat change in a protected National Seashore. Remote sensing methods were essential for understanding how these protected salt marshes changed from 1994 to 2017. This analysis was contingent on the proliferation of remote sensing data which allowed for the synthesis of multiple data types to better understand salt marsh trends and dynamics. Change analysis demonstrated that panne/pool expansion and edge erosion accounted for the majority of salt marsh loss. The losses were partly driven by an increase in edge erosion observed following the breach. Vegetation regrowth occurred with pannes/pools demonstrating increased regrowth when hydrologically connected to a mosquito ditch or channel. The pannes/pools analyzed were not in equilibrium in the two decades analyzed instead demonstrating a long-term trend of expansion.

There is a need for increased salt marsh monitoring for determining where, when, and how salt marshes are changing. This study presents a methodology for salt marsh classification and change analysis of pannes and edge erosion. The aerial imagery classifications achieved satisfactory overall accuracies $(>85 \%)$ as suggested by Thomlison et al. [68], however, propagated error when conducting the change analyses was a concern. NAIP imagery is an ideal data source in regards to spatial, temporal and spectral resolution with several caveats. The lack of a NIR band led to a decrease in accuracy due to vegetated and non-vegetated pannes appearing spectrally similar. Additionally, aerial image acquisitions had variable quality and tidal stages at time of acquisition which limited the accuracy of particular years. Finally, the data are only available for the USA. The workflow used in this study allowed for rapid classification and change analysis of salt marsh environments. The biennial collection of NAIP imagery makes it uniquely suited for the low-cost continuation of high-resolution salt marsh monitoring into the future.

Author Contributions: Conceptualization, A.C. and Y.W.; Formal Analysis, Y.W.; Funding Acquisition, Y.W.; Investigation, A.C. and Y.W.; Methodology, A.C. and Y.W.; Project administration, Y.W.; Resources, Y.W.; Software, 
Y.W.; Supervision, Y.W.; Validation, A.C.; Visualization, A.C.; Writing-Original Draft, A.C.; Writing一Review \& Editing, A.C. and Y.W.

Funding: This research was funded by U.S. National Park Service, grant number: P14AC00230.

Acknowledgments: This project was funded by the Northeast Coastal and Barrier Network (NCBN) of the National Park Service (NPS)'s Inventory \& Monitoring Program under the Task Agreement Number P14AC00230. We appreciate the guidance and support of Sara Stevens, Dennis Skidds, Bill Thompson, and Charles Roman of the NPS NCBN and North Atlantic Coast CESU. The authors appreciate the assistance by administrators and professionals from Fire Island National Seashore (FIIS), particularly Jordan Raphael for his expertise, insights, field guidance, and logistic support. Additionally, the authors would like to thank the three anonymous reviewers for their comments and constructive criticism.

Conflicts of Interest: The authors declare no conflict of interest.

\section{References}

1. Zedler, J.B.; Kercher, S. Wetland Resources: Status, Trends, Ecosystem Services, and Restorability. Annu. Rev. Environ. Resour. 2005, 30, 39-74. [CrossRef]

2. Barbier, E.B.; Hacker, S.D.; Kennedy, C.; Koch, E.W.; Stier, A.C.; Silliman, B.R. The Value of Estuarine and Coastal Ecosystem Services. Ecol. Monogr. 2011, 81, 169-193. [CrossRef]

3. Gedan, K.B.; Silliman, B.R.; Bertness, M.D. Centuries of Human-Driven Change in Salt Marsh Ecosystems. Annu. Rev. Mar. Sci. 2009, 1, 117-141. [CrossRef] [PubMed]

4. Crain, C.M.; Gedan, K.B.; Dionne, M. Tidal Restrictions and Mosquito Ditching in New England Marshes. In Human Impacts on Salt Marshes: A Global Perspective; University of California Press: Berkeley, CA, USA, 2009; pp. 149-169.

5. Crosby, S.C.; Sax, D.F.; Palmer, M.E.; Booth, H.S.; Deegan, L.A.; Bertness, M.D.; Leslie, H.M. Salt Marsh Persistence is Threatened by Predicted Sea-Level Rise. Estuar. Coast. Shelf Sci. 2016, 181, 93-99. [CrossRef]

6. Watson, E.B.; Raposa, K.B.; Carey, J.C.; Wigand, C.; Warren, R.S. Anthropocene Survival of Southern New England's Salt Marshes. Estuaries Coasts 2017, 40, 617-625. [CrossRef] [PubMed]

7. Wigand, C.; Roman, C.T.; Davey, E.; Stolt, M.; Johnson, R.; Hanson, A.; Watson, E.B.; Moran, S.B.; Cahoon, D.R.; Lynch, J.C. Below the Disappearing Marshes of an Urban Estuary: Historic Nitrogen Trends and Soil Structure. Ecol. Appl. 2014, 24, 633-649. [CrossRef] [PubMed]

8. Altieri, A.H.; Bertness, M.D.; Coverdale, T.C.; Herrmann, N.C.; Angelini, C. A Trophic Cascade Triggers Collapse of a Salt-marsh Ecosystem with Intensive Recreational Fishing. Ecology 2012, 93, 1402-1410. [CrossRef]

9. Deegan, L.A.; Johnson, D.S.; Warren, R.S.; Peterson, B.J.; Fleeger, J.W.; Fagherazzi, S.; Wollheim, W.M. Coastal Eutrophication as a Driver of Salt Marsh Loss. Nature 2012, 490, 388-392. [CrossRef]

10. Kirwan, M.L.; Guntenspergen, G.R. Influence of Tidal Range on the Stability of Coastal Marshland. J. Geophys. Res. Earth Surf. 2010, 115. [CrossRef]

11. Kirwan, M.L.; Murray, A.B.; Boyd, W.S. Temporary Vegetation Disturbance as an Explanation for Permanent Loss of Tidal Wetlands. Geophys. Res. Lett. 2008, 35. [CrossRef]

12. Holdredge, C.; Bertness, M.D.; Altieri, A.H. Role of Crab Herbivory in Die-Off of New England Salt Marshes. Conserv. Biol. 2009, 23, 672-679. [CrossRef]

13. Kearney, M.S.; Rogers, A.S.; Townshend, J.R.; Rizzo, E.; Stutzer, D.; Stevenson, J.C.; Sundborg, K. Landsat Imagery shows Decline of Coastal Marshes in Chesapeake and Delaware Bays. EOS Trans. Am. Geophys. Union 2002, 83, 173-178. [CrossRef]

14. Schepers, L.; Kirwan, M.; Guntenspergen, G.; Temmerman, S. Spatio-temporal Development of Vegetation Die-off in a Submerging Coastal Marsh. Limnol. Oceanogr. 2017, 62, 137-150. [CrossRef]

15. Cameron Engineering and Associates. Long Island Tidal Wetlands Trends Analysis; New England Interstate Water Pollution Control Commission: Lowell, MA, USA, 2015; 207p.

16. Watson, E.B.; Wigand, C.; Davey, E.W.; Andrews, H.M.; Bishop, J.; Raposa, K.B. Wetland Loss Patterns and Inundation-Productivity Relationships Prognosticate Widespread Salt Marsh Loss for Southern New England. Estuaries Coasts 2017, 40, 662-681. [CrossRef]

17. Schieder, N.W.; Walters, D.C.; Kirwan, M.L. Massive Upland to Wetland Conversion Compensated for Historical Marsh Loss in Chesapeake Bay, USA. Estuaries Coasts 2018, 41, 940-951. [CrossRef] 
18. Schuerch, M.; Spencer, T.; Temmerman, S.; Kirwan, M.L.; Wolff, C.; Lincke, D.; McOwen, C.J.; Pickering, M.D.; Reef, R.; Vafeidis, A.T. Future Response of Global Coastal Wetlands to Sea-Level Rise. Nature 2018, 561, 231. [CrossRef]

19. Marsh, A.; Blum, L.K.; Christian, R.R.; Ramsey, E.; Rangoonwala, A. Response and Resilience of Spartina Alterniflora. J. Coast. Conserv. 2016, 20, 335-350. [CrossRef]

20. Alber, M.; Swenson, E.M.; Adamowicz, S.C.; Mendelssohn, I.A. Salt Marsh Dieback: An Overview of Recent Events in the US. Estuar. Coast. Shelf Sci. 2008, 80,1-11. [CrossRef]

21. Kearney, M.S.; Turner, R.E. Microtidal Marshes: Can these Widespread and Fragile Marshes Survive Increasing Climate-sea Level Variability and Human Action? J. Coast. Res. 2016, 32, 686-699. [CrossRef]

22. Wilson, K.R.; Kelley, J.T.; Croitoru, A.; Dionne, M.; Belknap, D.F.; Steneck, R. Stratigraphic and Ecophysical Characterizations of Salt Pools: Dynamic Landforms of the Webhannet Salt Marsh, Wells, ME, USA. Estuaries Coasts 2009, 32, 855-870. [CrossRef]

23. Cowardin, L.M.; Carter, V.; Golet, F.C.; LaRoe, E.T. Classification of Wetlands and Deepwater Habitats of the United States; U.S. Department of the Interior: Washington, DC, USA, 1979; 131p.

24. Wilson, C.A.; Hughes, Z.J.; FitzGerald, D.M.; Hopkinson, C.S.; Valentine, V.; Kolker, A.S. Saltmarsh Pool and Tidal Creek Morphodynamics: Dynamic Equilibrium of Northern Latitude Saltmarshes? Geomorphology 2014, 213, 99-115. [CrossRef]

25. Mariotti, G. Revisiting Salt Marsh Resilience to Sea Level Rise: Are Ponds Responsible for Permanent Land Loss? J. Geophys. Res. Earth Surf. 2016, 121, 1391-1407. [CrossRef]

26. Hapke, C.J.; Brenner, O.; Hehre, R.; Reynolds, B.J. Coastal Change from Hurricane Sandy and the 2012-13 Winter Storm Season-Fire Island; Geological Survey Open-File Report; U.S. Geological Survey: Reston, VA, USA, 2013.

27. Leatherman, S.P. Geomorphic and Stratigraphic Analysis of Fire Island, New York. Mar. Geol. 1985, 63, 173-195. [CrossRef]

28. Friedrichs, C.T.; Perry, J.E. Tidal Salt Marsh Morphodynamics: A Synthesis. J. Coast. Res. 2001, 7-37. Available online: https://www.jstor.org/stable/25736162 (accessed on 15 January 2019).

29. Courtemanche, R.P., Jr.; Hester, M.W.; Mendelssohn, I.A. Recovery of a Louisiana Barrier Island Marsh Plant Community Following Extensive Hurricane-Induced Overwash. J. Coast. Res. 1999, 15, 872-883.

30. Roman, C.T.; King, D.R.; Cahoon, D.R.; Lynch, J.C.; Appleby, P.G. Evaluation of Marsh Development Processes at Fire Island National Seashore: Recent and Historic Perspectives; National Park Service: Boston, MA, USA, 2007.

31. Silvestri, S.; D’Alpaos, A.; Nordio, G.; Carniello, L. Anthropogenic Modifications can significantly Influence the Local Mean Sea Level and Affect the Survival of Salt Marshes in Shallow Tidal Systems. J. Geophys. Res. Earth Surf. 2018, 123, 996-1012.

32. Adamowicz, S.C.; Roman, C.T. New England Salt Marsh Pools: A Quantitative Analysis of Geomorphic and Geographic Features. Wetlands 2005, 25, 279-288. [CrossRef]

33. Millette, T.L.; Argow, B.A.; Marcano, E.; Hayward, C.; Hopkinson, C.S.; Valentine, V. Salt Marsh Geomorphological Analyses Via Integration of Multitemporal Multispectral Remote Sensing with LIDAR and GIS. J. Coast. Res. 2010, 26, 809-816. [CrossRef]

34. Smith, S.M. Vegetation Change in Salt Marshes of Cape Cod National Seashore (Massachusetts, USA) between 1984 and 2013. Wetlands 2015, 35, 127-136. [CrossRef]

35. Campbell, A.; Wang, Y.; Christiano, M.; Stevens, S. Salt Marsh Monitoring in Jamaica Bay, New York from 2003 to 2013: A Decade of Change from Restoration to Hurricane Sandy. Remote Sens. 2017, 9, 131. [CrossRef]

36. Sun, C.; Fagherazzi, S.; Liu, Y. Classification Mapping of Salt Marsh Vegetation by Flexible Monthly NDVI Time-Series using Landsat Imagery. Estuar. Coast. Shelf Sci. 2018, 213, 61-80. [CrossRef]

37. McElroy, A.; Benotti, M.; Edinger, G.; Feldmann, A.; O'Connell, C.; Steward, G.; Swanson, R.L.; Waldman, J. Assessment of Natural Resource Conditions: Fire Island National Seashore; Natural Resource Report NPS/NRPC/NRR; National Park Service: Fort Collins, CO, USA, 2009.

38. Hair, M.E.; Buckner, S. An Assessment of the Water Quality Characteristics of Great South Bay and Contiguous Streams; Adelphi University Institute of Marine Science: Garden City, NY, USA, 1973.

39. Lentz, E.E.; Hapke, C.J. Geologic Framework Influences on the Geomorphology of an Anthropogenically Modified Barrier Island: Assessment of Dune/Beach Changes at Fire Island, New York. Geomorphology 2011, 126, 82-96. [CrossRef] 
40. Leonardi, N.; Ganju, N.K.; Fagherazzi, S. A Linear Relationship between Wave Power and Erosion Determines Salt-Marsh Resilience to Violent Storms and Hurricanes. Proc. Natl. Acad. Sci. USA 2016, 113, 64-68. [CrossRef]

41. Aerts, J.C.; Lin, N.; Botzen, W.; Emanuel, K.; de Moel, H. Low-Probability Flood Risk Modeling for New York City. Risk Anal. 2013, 33, 772-788. [CrossRef]

42. Wang, Y.; Traber, M.; Milstead, B.; Stevens, S. Terrestrial and Submerged Aquatic Vegetation Mapping in Fire Island National Seashore using High Spatial Resolution Remote Sensing Data. Mar. Geod. 2007, 30, 77-95. [CrossRef]

43. U.S. Geological Survey (USGS). USGS Surface-Water Daily Data for New York. Watch Hill, NY, USA, 2017. Available online: https://waterdata.usgs.gov/ny/nwis/uv?site_no=01305575 (accessed on 15 January 2019).

44. Morgan, K.L.M.; Krohn, M.D. Post-Hurricane Sandy Coastal Oblique Aerial Photographs Collected from Cape Lookout, North Carolina, to Montauk, New York, November 4-6, 2012; U.S. Geological Survey Data Series 858; U.S. Geological Survey: Reston, VA, USA, 2014. [CrossRef]

45. Conservation Management Institute, NatureServe, and New York Natural Heritage Program. Fire Island National Seashore Vegetation Inventory Project_Spatial Vegetation Data; National Park Service: Denver, CO, USA, 2002. Available online: https://www.sciencebase.gov/catalog/item/541ca909e4b0e96537e0a41e (accessed on 15 January 2019).

46. Klopfer, S.D.; Olivero, A.; Sneddon, L.; Lundgren, J. Final Report of the NPS Vegetation Mapping Project at Fire Island National Seashore; Conservation Management Institute-Virginia Tech: Blacksburg, VA, USA, 2002.

47. U.S. Geological Survey (USGS). USGS Surface-Water Daily Data for New York. Lindenhurst, NY, USA, 2017. Available online: https://waterdata.usgs.gov/ny/nwis/uv?site_no=01309225 (accessed on 15 January 2019).

48. Jensen, J.R.; Cowen, D.J.; Althausen, J.D.; Narumalani, S.; Weatherbee, O. The Detection and Prediction of Sea Level Changes on Coastal Wetlands using Satellite Imagery and a Geographic Information System. Geocarto Int. 1993, 8, 87-98. [CrossRef]

49. Jensen, J.R.; Cowen, D.J.; Althausen, J.D.; Narumalani, S.; Weatherbee, O. An Evaluation of the CoastWatch Change Detection Protocol in South Carolina. Photogramm. Eng. Remote Sens. 1993, 59, 1039-1044.

50. Campbell, A.; Wang, Y. Examining the Influence of Tidal Stage on Salt Marsh Mapping using High-Spatial-Resolution Satellite Remote Sensing and Topobathymetric Lidar. IEEE Trans. Geosci. Remote Sens. 2018, 56, 5169-5176. [CrossRef]

51. Hay, G.J.; Castilla, G. Geographic Object-Based Image Analysis (GEOBIA): A new name for a new discipline. In Object-Based Image Analysis; Blaschke, T., Lang, S., Hay, G.J., Eds.; Springer: Berlin, Germany, 2008; pp. 75-89.

52. Bo, S.; Ding, L.; Li, H.; Di, F.; Zhu, C. Mean Shift-based Clustering Analysis of Multispectral Remote Sensing Imagery. Int. J. Remote Sens. 2009, 30, 817-827. [CrossRef]

53. Yang, G.; Pu, R.; Zhang, J.; Zhao, C.; Feng, H.; Wang, J. Remote Sensing of Seasonal Variability of Fractional Vegetation Cover and its Object-Based Spatial Pattern Analysis Over Mountain Areas. ISPRS J. Photogramm. Remote Sens. 2013, 77, 79-93. [CrossRef]

54. Castillejo-González, I.L.; López-Granados, F.; García-Ferrer, A.; Peña-Barragán, J.M.; Jurado-Expósito, M.; de la Orden, M.S.; González-Audicana, M. Object- and Pixel-Based Analysis for Mapping Crops and their Agro-Environmental Associated Measures using QuickBird Imagery. Comput. Electron. Agric. 2009, 68, 207-215. [CrossRef]

55. Myint, S.W.; Gober, P.; Brazel, A.; Grossman-Clarke, S.; Weng, Q. Per-Pixel vs. Object-Based Classification of Urban Land Cover Extraction using High Spatial Resolution Imagery. Remote Sens. Environ. 2011, 115, 1145-1161. [CrossRef]

56. Lantz, N.J.; Wang, J. Object-Based Classification of Worldview-2 Imagery for Mapping Invasive Common Reed, Phragmites Australis. Can. J. Remote Sens. 2013, 39, 328-340. [CrossRef]

57. Espindola, G.M.; Câmara, G.; Reis, I.A.; Bins, L.S.; Monteiro, A.M. Parameter Selection for Region-growing Image Segmentation Algorithms using Spatial Autocorrelation. Int. J. Remote Sens. 2006, 27, 3035-3040. [CrossRef]

58. Johnson, B.; Xie, Z. Unsupervised Image Segmentation Evaluation and Refinement using a Multi-Scale Approach. ISPRS J. Photogramm. Remote Sens. 2011, 66, 473-483. [CrossRef]

59. Rossum, G.V. Python Tutorial; Technical Report CS-R9526; Centrum voor Wiskunde en Informatica (CWI): Amsterdam, The Netherlands, 1995. 
60. Inglada, J.; Christophe, E. The Orfeo Toolbox Remote Sensing Image Processing Software. In Proceedings of the 2009 IEEE International Geoscience and Remote Sensing Symposium, Cape Town, South Africa, 12-17 July 2009; p. 736.

61. Corman, S.S.; Roman, C.T.; King, J.W.; Appleby, P.G. Salt Marsh Mosquito-Control Ditches: Sedimentation, Landscape Change, and Restoration Implications. J. Coast. Res. 2012, 28, 874-880. [CrossRef]

62. ESRI 2016-ArcGIS Desktop: Release 10.5; Environmental Systems Research Institute: Redlands, CA, USA, 2016.

63. R Core Team. R: A Language and Environment for Statistical Computing; Version 3.5.0; R Foundation for Statistical Computing: Vienna, Austria, 2018.

64. Johnston, R.J.; Grigalunas, T.A.; Opaluch, J.J.; Mazzotta, M.; Diamantedes, J. Valuing Estuarine Resource Services using Economic and Ecological Models: The Peconic Estuary System Study. Coast. Manag. 2002, 30, 47-65. [CrossRef]

65. Vincent, R.E.; Burdick, D.M.; Dionne, M. Ditching and Ditch-Plugging in New England Salt Marshes: Effects on Hydrology, Elevation, and Soil Characteristics. Estuaries Coasts 2013, 36, 610-625. [CrossRef]

66. Watson, E.B. Wetland Elevation Changes: Expansion of Pannes. Sound Update, Newsletter of the Long Island Sound Study 2015. Available online: http://longislandsoundstudy.net/wp-content/uploads/2015/06/ SoundUpdate_TidalWetlandsLoss_forweb.pdf (accessed on 15 January 2019).

67. Rasmussen, S.A.; Neil, A.J. Marsh Elevation Points for Assateague Island National Seashore, Fire Island National Seashore, and Gateway National Recreation Area-Sandy Hook Unit; Environmental Data Center: Kingston, RI, USA, 2017.

68. Thomlinson, J.R.; Bolstad, P.V.; Cohen, W.B. Coordinating Methodologies for Scaling Landcover Classifications from Site-Specific to Global: Steps Toward Validating Global Map Products. Remote Sens. Environ. 1999, 70, 16-28. [CrossRef]

(C) 2019 by the authors. Licensee MDPI, Basel, Switzerland. This article is an open access article distributed under the terms and conditions of the Creative Commons Attribution (CC BY) license (http://creativecommons.org/licenses/by/4.0/). 